\title{
Comparison of the acidification activities of commercial starter cultures in camel and
} bovine milk

Berhe, Tesfemariam; Ipsen, Richard; Seifu, Eyassu; Kurtu, Mohammed Y.; Eshetu, Mitiku; Hansen, Egon Bech

Published in:

L W T- Food Science and Technology

Link to article, DOI:

10.1016/j.Iwt.2017.10.041

Publication date:

2018

Document Version

Peer reviewed version

Link back to DTU Orbit

Citation (APA):

Berhe, T., Ipsen, R., Seifu, E., Kurtu, M. Y., Eshetu, M., \& Hansen, E. B. (2018). Comparison of the acidification activities of commercial starter cultures in camel and bovine milk. $L W T$ - Food Science and Technology, 89, 123-127. https://doi.org/10.1016/j.lwt.2017.10.041

\section{General rights}

Copyright and moral rights for the publications made accessible in the public portal are retained by the authors and/or other copyright owners and it is a condition of accessing publications that users recognise and abide by the legal requirements associated with these rights.

- Users may download and print one copy of any publication from the public portal for the purpose of private study or research.

- You may not further distribute the material or use it for any profit-making activity or commercial gain

- You may freely distribute the URL identifying the publication in the public portal 


\section{Accepted Manuscript}

Comparison of the acidification activities of commercial starter cultures in camel and bovine milk

Tesfemariam Berhe, Richard Ipsen, Eyassu Seifu, Mohammed Y. Kurtu, Mitiku Eshetu, Egon Bech Hansen

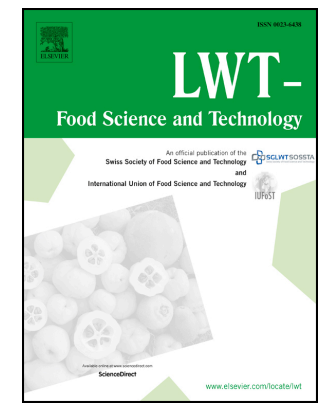

PII:

S0023-6438(17)30794-6

DOI:

10.1016/j.Iwt.2017.10.041

Reference: YFSTL 6604

To appear in: $\quad$ LWT - Food Science and Technology

Received Date: 9 March 2017

Revised Date: 19 October 2017

Accepted Date: 20 October 2017

Please cite this article as: Berhe, T., Ipsen, R., Seifu, E., Kurtu, M.Y., Eshetu, M., Hansen, E.B., Comparison of the acidification activities of commercial starter cultures in camel and bovine milk, LWT Food Science and Technology (2017), doi: 10.1016/j.Iwt.2017.10.041.

This is a PDF file of an unedited manuscript that has been accepted for publication. As a service to our customers we are providing this early version of the manuscript. The manuscript will undergo copyediting, typesetting, and review of the resulting proof before it is published in its final form. Please note that during the production process errors may be discovered which could affect the content, and all legal disclaimers that apply to the journal pertain. 
1 Comparison of the Acidification Activities of Commercial Starter Cultures in Camel

2 and Bovine Milk

3

4 Tesfemariam Berhe ${ }^{\text {ab* }}$, Richard Ipsen ${ }^{\mathrm{b}}$, Eyassu Seifu ${ }^{\mathrm{c}}$, Mohammed Y. Kurtu $^{\mathrm{a}}$, Mitiku Eshetu ${ }^{\mathrm{a}}$

5 Egon Bech Hansen ${ }^{\mathrm{d}}$

6

$7{ }^{a}$ School of Animal and Range Sciences, Haramaya University, P.O. Box: 138, Dire Dawa,

8 Ethiopia

$9{ }^{b}$ Department of Food Science, University of Copenhagen, Rolighedsvej 30, 1958

$10 \quad$ Frederiksberg $C$, Denmark

$11{ }^{c}$ Department of Food Science and Technology, Botswana University of Agriculture and

12 Natural Resources, Private Bag: 0027, Botswana

$13{ }^{d}$ Division for Diet, Disease Prevention and Toxicology, National Food Institute, Technical 14 University of Denmark, 2800 Kgs. Lyngby, Denmark

15

16

17

18

19

20

21

22

23

24

25

* Corresponding author:

Tesfemariam Berhe

School of Animal and Range Sciences

Haramaya University

P.O. Box: 138, Dire Dawa, Ethiopia

Phone: $+251-912-029186$

Fax: +251-25-553-0052

E-mail:Lucyselam@gmail.com 


\section{Abstract}

27 Camel milk has been reported to be difficult to ferment due to anti-microbial properties. The 28 present study tested eight commercial starter cultures for their ability to grow in camel milk.

29 All investigated cultures were able to acidify camel milk and reached a final $\mathrm{pH}$ at a level 30 similar to what was achieved in bovine milk, but the speed of acidification was generally 31 lower in camel milk. This could be due to inhibitory substances in camel milk or due to 32 reduced availability of nutrients. Experiments using mixtures of camel and bovine milk or supplementation with casein hydrolysates allowed us to distinguish between these possibilities. High acidification rates were obtained in camel milk mixed with bovine milk or supplemented with casein hydrolysate. This demonstrates that the cultures are not inhibited by camel milk and we conclude that the growth rates of these cultures in pure camel milk are

37 limited by the rate of proteolysis.

39 Key words; acidification activity, fermented camel milk, dairy starter cultures, lactic acid 40 bacteria, proteolysis 


\section{Introduction}

Camels (Camelus dromedarius) are significant for many pastoralist communities of the dry zones of sub-Saharan Africa by providing milk, meat and transportation. More than half of the world's 28 million camels are found in the East African countries of Somalia, Sudan, Ethiopia and Kenya (FAO STAT, 2014). Camel milk has a gross composition similar to bovine milk. However, the relative composition, distribution and the molecular structures of the milk components are different and e.g. $\beta$-lactoglobulin is absent in camel milk. The sequence homology between milk proteins from camel and cow is in the range of 60 to $90 \%$ (Kappeler, Farah, \& Puhan, 1998).

It is commonly claimed that camel milk is technically more difficult to process into products than milk from other livestock and that it is only suitable for drinking (Al haj \& Al Kanhal, 2010). Only few investigations have dealt with the possibilities of making camel dairy products through diligent adjustments in the technology. Some improvement of the production of butter (Berhe, Seifu, \& Kurtu, 2013; Farah, Streiff, \& Bachmann, 1989), cheese (Ahmed \& Kanwal, 2004; Mehaia, 2006), and yoghurt (Ibrahem \& El Zubeir, 2016; Hashim, Khalil, \& Habib, 2009) have been described. Hence, there seems to be ample possibility to design and develop novel dairy products from camel milk.

Camel milk has been reported to be difficult to ferment because of the high content of antimicrobial components, thus, hindering acidification and curd formation (El-Agamy, Ruppanner, Ismail, Champagne, \& Assaf, 1992). The relative concentration of lysozyme, lactoferrin, lactoperoxidase and immunoglobulins in camel milk is reported to be higher than for bovine milk (Elagamy, 2000; Kappeler, Ackermann, Farah, \& Puhan, 1999; Konuspayeva, Faye, Loiseau, \& Levieux, 2007). Effective starter cultures are needed in order to produce value added fermented camel dairy products with extended shelf life. Currently, there are commercial starter cultures developed for bovine, sheep, and goat dairy industries. However, no data is available concerning the fermentation potential of such commercial starter cultures on camel milk. Therefore, the current research was undertaken to thoroughly characterize the acidification activities of commercial starter cultures in camel milk in comparison to bovine milk. This can ensure selection of better performing cultures and the optimization of incubation temperatures for fermentation of camel milk. 


\section{Materials and Methods}

Pooled Camel milk (10 camels) and bovine milk (10 cows) samples were collected from Babile area and Haramaya University dairy farm in Ethiopia respectively. Eight lyophilized commercial starter cultures in 50-unit sachets were obtained from Chr. Hansen A/S (Denmark) (Table 1). The unit for starter cultures used by Chr Hansen A/S is defined as the activity of $100 \mathrm{ml}$ of an active bulk starter culture and one unit of culture is suitable for the inoculation of 10 liters of milk.

Standardized inoculums were prepared by resuspending a 50-unit sachet of culture in $500 \mathrm{ml}$ of autoclaved bovine milk. The resuspended cultures were distributed into $100 \mathrm{ml}$ bottles and frozen at $-20^{\circ} \mathrm{C}$. Fermentation experiments were conducted in milk which had been pasteurized at $65{ }^{\circ} \mathrm{C}$ for 30 minutes and cooled to the incubation temperatures. Inoculation of $250 \mathrm{ml}$ portions of milk was done by adding $0.5 \mathrm{ml}$ of the thawed inoculum. This is approximately twice the standard inoculation rate compared to direct use of the lyophilized culture. The increased rate of inoculation was used to compensate for the potential loss of activity due to the extra freeze-thaw procedure.

When milk was supplemented with casein hydrolysate, a level of $0.5 \%$ (w/v) was reached by adding 1/20 of the volume of $10 \%$ (w/v) casein hydrolysate (Sigma-Aldrich nr. 22090) dissolved in water. The stock solution had been autoclaved prior to use. Fermentations were conducted at 30 and $37{ }^{\circ} \mathrm{C}$ for the cultures R-704, R-707 and CHN-22; at 30, 37, and $42{ }^{\circ} \mathrm{C}$ for the cultures RST-743 and XPL-2; and at 37 and $42{ }^{\circ} \mathrm{C}$ for the cultures Yoflex mild 1.0, YF-L904 and STI-12. Acidifications were followed for 18 hours using an iCinac instrument (Alliance Instruments, Frepillon, France) which measures the $\mathrm{pH}$, oxidation reduction potential and temperature of the culture simultaneously. The iCinac probes were first calibrated as per the manufacturer manual using buffers 4 and 7 supplied from the same company. The experiment was repeated two times and analysis was done in duplicate. $\mathrm{V}_{\max }$ and time to $\mathrm{pH} 4.6$ were the parameters used to characterize the acidification activities of the starter cultures. $\mathrm{V}_{\max }$ is the maximum acidification speed of $\mathrm{pH}$ drop per minute during the fermentation course. High acidification activity is equivalent to a high $\mathrm{V}_{\max }$ and a short time to $\mathrm{pH}$ to 4.6. The $\mathrm{V}_{\max }$ and time to $\mathrm{pH} 4.6$ values are extracted from the acidification curves. Statistix 10.0 was used for data analysis. A three way full factorial design was used for the experiment taking $\mathrm{V}_{\max }$ and $\mathrm{pH}$ to 4.6 as response variables. Least significant difference at $(\alpha=0.5)$ was used for the mean comparison. The data were categorized into three groups and analyzed separately. Group I comprised of the mesophilic starter cultures (R-704, R-707 and CHN-22), group II comprised of mixed strains of 
107 thermophilic and mesophilic cultures (RST-743 and XPL-2), and Group III comprised of 108 thermophilic starter cultures (STI-12, Yoflex mild 1.0 and YF-L904). 


\section{Results and discussion}

Tables 2 and 3 give the $\mathrm{V}_{\max }$ and time to $\mathrm{pH} 4.6$ of the eight investigated starter cultures in camel and bovine milk. Selected acidification curves obtained with those cultures are given in Figure 1.

There were significant differences $(\mathrm{p}<0.05)$ in the acidification activities of the cultures between camel and bovine milk and within the different incubation temperatures (Tables 2 and 3). The $\mathrm{V}_{\max }$ and $\mathrm{pH}$ to 4.6 of group I cultures (R-704, R-707 and $\mathrm{CHN}-22$ ) showed higher acidification activities at 30 than $37^{\circ} \mathrm{C}$ in camel milk. Moreover, the acidification activities in bovine milk were higher than in camel milk at their corresponding incubation temperatures (Tables 2 and 3). The acidification curves for R-707, CHN-22 and STI-12 are presented in Figure 1. Similar acidification trends were observed for all three cultures of group I: incubation temperature of $30{ }^{\circ} \mathrm{C}$ was optimum and bovine milk was superior in acidification activities to camel milk. Thus, incubation temperature of $30{ }^{\circ} \mathrm{C}$ is recommended for the fermentation of camel milk using R-704, R-707 and CHN-22 starter cultures. The time to reach pH 4.6 in camel milk incubated at $30^{\circ} \mathrm{C}$ was 8:10, 12:35 and 12:40 hours for R-707, CHN-22 and R-704, respectively. Therefore, R-707 is the best for the fermentation of camel milk among the three mesophilic starter cultures.

$\mathrm{V}_{\max }$ values of RST-743 and XPL-2 under group II (Tables 2 and 3) cultures showed in camel milk highest acidification activities at $42^{\circ} \mathrm{C}$. There were no significant differences in $\mathrm{v}_{\max }$ values of XPL-2 and RST-743 between 30 and $37^{\circ} \mathrm{C}$ in camel milk. For RST-743 no significant difference in time to reach $\mathrm{pH} 4.6$ was observed among the three incubation temperatures in camel milk. This may be attributed to the mixed strains of the culture that covers the mesophilic and thermophilic growth temperature ranges. Generally, higher acidification activities were observed in bovine milk than their corresponding values in camel milk. The acidification activity was higher in RST-743 than XPL-2 at the optimum incubation temperature.

Values of $\mathrm{V}_{\max }$ for Yoflex mild.10 and YF-L904 under group III did not show significant difference between the incubation temperatures of 37 and $42{ }^{\circ} \mathrm{C}$ in camel milk. Similarly, values of $\mathrm{pH}$ to 4.6 for YF-L904 and STI-12 under group III did not show significant difference between the incubation temperatures of 37 and $42{ }^{\circ} \mathrm{C}$ in camel milk (Tables 2 and 3). However, Higher $\mathrm{V}_{\max }$ value of STI-12 was observed at $42{ }^{\circ} \mathrm{C}$ than $37^{\circ} \mathrm{C}$ in camel milk. Similar to the mesophilic starter cultures, the thermophilic cultures showed slower acidification activities in camel milk than bovine milk. STI-12 was the best among the thermophilic starter culture for the acidification of camel milk at $42{ }^{\circ} \mathrm{C}$. 
As a conclusion, all cultures were able to acidify camel milk and reached a final $\mathrm{pH}$ at a level similar to bovine milk, but the speed of acidification of all tested cultures was lower in camel milk than the corresponding bovine milk. The delay in fermentation time of the cultures in camel milk from cow milk was from 1:15 to 4:10 hours under the corresponding optimum incubation temperatures. This study has shown that camel milk could be acidified satisfactorily to the level that was achieved in bovine milk using commercial cultures. This disproves the claims that camel milk cannot be satisfactorily acidified due to its antimicrobial properties (El Agamy et al., 1992). A recent report Habtegebriel \& Admassu (2016) also indicated that it was possible to acidify camel milk to $\mathrm{pH} 4.3$ using commercial cultures. To analyse if the delay of the acidification in camel milk is caused by antimicrobial activities in camel milk or if it is due to reduced availability of nutrients, we analyzed the acidification in milk supplemented with casein hydrolysate and in a 50:50 blend of camel and bovine milk. The acidification activities were tested using R-707 and Yoflex mild 1.0 at incubation temperatures of 30 and $42{ }^{\circ} \mathrm{C}$ respectively. The acidification activities in the casein hydrolysate supplemented camel milk were higher than in the non-supplemented camel milk and similar to the supplemented bovine milk. Moreover, also blending of camel milk with bovine milk improved the speed of acidification to a level similar to the acidification activity in bovine milk (Table 4 and Figure 2).

There was no significant difference in time to $\mathrm{pH} 4.6$ values among the 50:50 blend and supplemented camel and bovine milk samples. For R-707 the time to $\mathrm{pH} 4.6$ in camel milk at $30{ }^{\circ} \mathrm{C}$ was 8:10 hours. The fermentation time was reduced to $6: 46$ hours when supplemented by casein hydrolysate and to 5:48 hours when blended with bovine milk. For Yoflex mild 1.0 the fermentation time was reduced from 9:08 hours in camel milk to 3:20 in supplemented camel milk and 3:55 hours in the mixed milk.

This shows that addition of amino acids in the form of casein hydrolysate or addition of bovine milk can alleviate the delay of fermentation in camel milk. Based on this result we can conclude that antimicrobial activities are not responsible for the delay. Our conclusion is that the proteolytic systems of the tested cultures are unable in camel milk to support a growth rate as fast as in bovine milk. Although this conclusion is firmly based on the results of our experiments, it is less obvious to explain why the rate of proteolysis is lower in camel milk. Beta casein is the preferred substrate for the proteinases of lactic acid bacteria (Siezen, 1999) and camel milk is rich in beta casein (Kappeler et al., 1998). The cause of the retardation is therefore not obvious. It will be interesting to investigate why the beta casein of camel milk is less accessible than the beta casein of bovine milk. 
178 3.1. Conclusion

179 Eight commercial starter cultures were tested and all were able to acidify camel milk and 180 reach a final $\mathrm{pH}$ at a level similar to bovine milk. However, the speed of acidification was 181 generally lower in camel milk than bovine milk. We have demonstrated that the difference in 182 speed in the two types of milk is due to difference in proteolysis rather than the presence of 183 inhibitory substance in camel milk. R-707 was found to be the best mesophilic culture and 184 STI-12 the best thermophilic culture for camel milk fermentation 
186 4. Acknowledgements

187 We want to express our great thanks to Danish International Development Agency (Danida)

188 for funding "Haramaya Camel Dairy Project" through the grant 12-017DTU.

189 We are grateful to Chr Hansen A/S for generously providing lyophilized cultures for the 190 project.

191 


\section{References}

Ahmed, T., \& Kanwal, R. (2004). Biochemical characteristics of lactic acid producing bacteria and preparation of camel milk cheese by using starter culture. Pakistan Veterinary Journal, 24(2), 87-91. Retrieved from www.pvj.com.pk/pdf-files/24_2/8791.pdf

Al haj, O. A., \& Al Kanhal, H. A. (2010). Compositional, technological and nutritional aspects of dromedary camel milk. International Dairy Journal, 20(12), 811-821. http://doi.org/10.1016/j.idairyj.2010.04.003

Berhe, T., Seifu, E., \& Kurtu, M. Y. (2013). Physicochemical properties of butter made from camel milk. International Dairy Journal, 31(2), 51-54. http://doi.org/10.1016/j.idairyj.2013.02.008

El Agamy, E. I., Ruppanner, R., Ismail, A., Champagne, C. P., \& Assaf, R. (1992). Antibacterial and antiviral activity of camel milk protective proteins. The Journal of Dairy Research, 59(2), 169-175. http://doi.org/10.1017/S0022029900030417

Elagamy, E. I. (2000). Effect of heat treatment on camel milk proteins with respect to antimicrobial factors: a comparison with cow and buffalo milk proteins. Food Chemistry, 68(2), 227-232. http://doi.org/10.1016/S0308-8146(99)00199-5

FAO stat, 2014. Availlable: http://faostat3.fao.org/. (2008).

Farah, Z., Streiff, T., \& Bachmann, M. R. (1989). Manufacture and characterization of camel milk butter. Milchwissenschaft, 44(7), 412-414.

Habtegebriel, H., \& Admassu, S. (2016). Optimization of the Processing Conditions of Stirred Yoghurt from Camel Milk using Linear Programming Technique. Food Science and Quality Management, 53, 33-38.

Hashim, I. . B., Khalil, A. H., \& Habib, H. (2009). Quality and acceptability of a set-type yogurt made from camel milk. Journal of Dairy Science, 92(3), 857-862. http://doi.org/http://dx.doi.org/10.3168/jds.2008-1408

Ibrahem, S. A., \& El Zubeir, I. E. M. (2016). Processing, composition and sensory characteristic of yoghurt made from camel milk and camel-sheep milk mixtures. Small Ruminant Research, 136, 109-112. http://doi.org/10.1016/j.smallrumres.2016.01.014

Kappeler, S., Farah, Z., \& Puhan, Z. (1998). Sequence analysis of Camelus dromedarius milk caseins. The Journal of Dairy Research, 65(2), 209-222. http://doi.org/10.1017/S0022029997002847

Kappeler, S. R., Ackermann, M., Farah, Z., \& Puhan, Z. (1999). Sequence analysis of camel ( Camelus dromedarius ) lactoferrin. International Dairy Journal, 9(x), 481-486.

Konuspayeva, G., Faye, B., Loiseau, G., \& Levieux, D. (2007). Lactoferrin and immunoglobulin contents in camel's milk (Camelus bactrianus, Camelus dromedarius, and Hybrids) from Kazakhstan. Journal of Dairy Science, 90(1), 38-46. http://doi.org/10.3168/jds.S0022-0302(07)72606-1

Mehaia, M. (2006). Manufacture of fresh soft white cheese (Domiati type) from dromedary camel's milk using ultrafiltration process. Journal of Food Technology.

Siezen, R. J. (1999). Multi-domain, cell-envelope proteinases of lactic acid bacteria. Antonie van Leeuwenhoek, International Journal of General and Molecular Microbiology, 76(14), 139-155. http://doi.org/10.1023/A:1002036906922 
1 Figure 1: Acidification curves of R-707, CHN-22 and STI-12 cultures in camel and bovine

2 milk incubated at their respective optimum temperatures.

3 Figure 2: Acidification curves of the R-707 culture incubated at $30{ }^{\circ} \mathrm{C}$ in camel, bovine,

$4 \quad 50: 50$ blend and casein hydrolysate supplemented milk

5 
1 Table 1: Description of the starter cultures used in the study

\begin{tabular}{lll}
\hline Culture & Taxonomy & Description \\
\hline R-704 & $\begin{array}{l}\text { Lactococcus lactis subsp. lactis } \\
\text { Lactococcus lactis subsp. cremoris }\end{array}$ & $\begin{array}{l}\text { Mesophilic homo- } \\
\text { fermentative O-culture }\end{array}$ \\
R-707 & $\begin{array}{l}\text { Lactococcus lactis subsp. lactis } \\
\text { Lactococcus lactis subsp. cremoris }\end{array}$ & $\begin{array}{l}\text { Mesophilic homo- } \\
\text { fermentative }\end{array}$ \\
O-culture
\end{tabular}


4 Table 2: Comparison of acidification activities of commercial starter cultures inoculated into

5 camel and bovine milk.

\begin{tabular}{|c|c|c|c|c|c|c|c|}
\hline \multirow[t]{2}{*}{ Group } & \multirow[t]{2}{*}{ Culture } & \multicolumn{2}{|c|}{$\begin{array}{l}\text { Camel milk } \\
\mathrm{V}_{\max }(\Delta \mathrm{pH} / \text { minute })\end{array}$} & \multirow[b]{2}{*}{$42^{\circ} \mathrm{C}$} & \multicolumn{2}{|c|}{$\begin{array}{l}\text { Bovine milk } \\
\mathrm{V}_{\max }(\Delta \mathrm{pH} / \text { minute })\end{array}$} & \multirow[b]{2}{*}{$42^{\circ} \mathrm{C}$} \\
\hline & & $30^{\circ} \mathrm{C}$ & $37^{\circ} \mathrm{C}$ & & $30{ }^{\circ} \mathrm{C}$ & $37^{\circ} \mathrm{C}$ & \\
\hline \multirow{3}{*}{$\begin{array}{l}\text { I } \\
\text { (Mesophilic cultures ) }\end{array}$} & R-704 & $-0.0051^{f}$ & $-0.0023^{i}$ & & $-0.0082^{\mathrm{c}}$ & $-0.0069^{d}$ & \\
\hline & R-707 & $-0.0080^{b c}$ & $-0.0047^{\mathrm{fg}}$ & & $-0.0099^{\mathrm{a}}$ & $-0.0093^{a b}$ & \\
\hline & CHN-22 & $-0.0060^{\mathrm{e}}$ & $-0.0033^{h}$ & & $-0.0080^{c}$ & $-0.0042^{\mathrm{g}}$ & $y$ \\
\hline \multirow{2}{*}{$\begin{array}{l}\text { II } \\
\text { (Mixture of } \\
\text { mesophile and } \\
\text { thermophile starains) }\end{array}$} & RST-743 & $-0.0066^{\mathrm{e}}$ & $-0.0060^{\text {ef }}$ & $-0.0079^{\mathrm{d}}$ & $-0.0081^{\mathrm{d}}$ & $-0.0117^{b}$ & $-0.0166^{\mathrm{a}}$ \\
\hline & XPL-2 & $-0.0042^{\mathrm{g}}$ & $-0.0052^{f g}$ & $-0.0069^{\mathrm{de}}$ & $-0.0080^{\mathrm{d}}$ & $-0.0099^{\mathrm{c}}$ & $-0.0117^{b}$ \\
\hline \multirow{3}{*}{$\begin{array}{l}\text { III (Thermophilic } \\
\text { cultures) }\end{array}$} & $\begin{array}{l}\text { Yoflex } \\
\text { mild } 1.0\end{array}$ & & $-0.0067^{\mathrm{g}}$ & $-0.0071^{\mathrm{g}}$ & & $-0.0116^{d}$ & $-0.0157^{b c}$ \\
\hline & YF-L904 & & $-0.0073^{f g}$ & $-0.0081^{\mathrm{f}}$ & & & $-0.0161^{b}$ \\
\hline & STI-12 & & $-0.0081^{f}$ & $-0.0093^{\mathrm{e}}$ & & $-0.0157^{b c}$ & $-0.0173^{\mathrm{a}}$ \\
\hline
\end{tabular}

6 Results are mean values of four analysis, means with the same letter across columns and rows within group are

7 not significantly different ( $p>0.05$ ), CV (coefficient of variation) $=5.2,6.5,3.6$ for Group I, II, and III

8 respectively. 
10 Table 3: Comparison of the time to reach $\mathrm{pH} 4.6$ of commercial starter cultures inoculated

11 into camel and bovine milk.

\begin{tabular}{|c|c|c|c|c|c|c|c|}
\hline \multirow[t]{2}{*}{ Group } & \multirow[t]{2}{*}{ Culture } & \multicolumn{2}{|c|}{$\begin{array}{l}\text { Camel milk } \\
\text { Time to } \mathrm{pH} 4.6 \text { (h:min) }\end{array}$} & \multicolumn{4}{|c|}{$\begin{array}{l}\text { Bovine milk } \\
\text { Time to } \mathrm{pH} 4.6 \text { (h:min) }\end{array}$} \\
\hline & & $30{ }^{\circ} \mathrm{C}$ & $37^{\circ} \mathrm{C}$ & $42^{\circ} \mathrm{C}$ & $30^{\circ} \mathrm{C}$ & $37^{\circ} \mathrm{C}$ & $42{ }^{\circ} \mathrm{C}$ \\
\hline \multirow{3}{*}{ I (mesophilic cultures) } & R-704 & $12: 40^{\mathrm{c}}$ & $16: 48^{b}$ & & $8: 25^{\mathrm{de}}$ & $9: 35^{\mathrm{d}}$ & \\
\hline & $\mathrm{R}-707$ & $8: 10^{\mathrm{de}}$ & $16: 05^{\mathrm{b}}$ & & $5: 55^{\mathrm{f}}$ & $7: 35^{\mathrm{ef}}$ & \\
\hline & CHN-22 & $12: 35^{\mathrm{c}}$ & $21: 15^{\mathrm{a}}$ & & $9: 10^{\text {de }}$ & $19: 45^{\mathrm{a}}$ & \\
\hline \multirow{2}{*}{$\begin{array}{l}\text { II (Mixture of mesophile } \\
\text { and thermophile strains) }\end{array}$} & RST-743 & $7: 55^{\mathrm{ef}}$ & $7: 52^{\mathrm{ef}}$ & $7: 23^{f}$ & $7: 40^{f}$ & $5: 05^{\mathrm{g}}$ & $4: 50^{g}$ \\
\hline & XPL-2 & $13: 40^{\mathrm{b}}$ & $15: 08^{\mathrm{a}}$ & $9: 58^{\mathrm{d}}$ & $11: 20^{\mathrm{c}}$ & $8: 54^{\text {de }}$ & $7: 30^{\mathrm{f}}$ \\
\hline \multirow{3}{*}{$\begin{array}{l}\text { III (Thermophilic } \\
\text { cultures) }\end{array}$} & $\begin{array}{l}\text { Yoflex mild } \\
1.0\end{array}$ & & $8: 30^{\mathrm{a}}$ & $8: 27^{\mathrm{a}}$ & & $4: 30^{\text {cde }}$ & $3: 45^{\text {ef }}$ \\
\hline & YF-L904 & & $8: 42^{\mathrm{a}}$ & $8: 37^{\mathrm{a}}$ & & $4: 39^{\mathrm{cd}}$ & $4: 03^{\mathrm{def}}$ \\
\hline & STI-12 & & $5: 32^{b}$ & $5: 10^{\mathrm{bc}}$ & & $4: 18^{\mathrm{def}}$ & $3: 35^{\mathrm{f}}$ \\
\hline
\end{tabular}

Results are mean values of four analysis, means with the same letter across columns and rows within group are not significantly different ( $p>0.05$ ), Coefficient of variation $(\mathrm{CV})=7.4,8.6,7.7$ for Group I, II and III

14 respectively. 
21 Table 4: Acidification activities of R-707 and Yoflex mild 1.0 in camel, bovine, 50:50 mix

22 and casein hydrolysate supplemented milk

\begin{tabular}{llll}
\hline Culture & Milk & $\mathrm{V}_{\max }(\Delta \mathrm{pH} /$ minute $)$ & $\begin{array}{l}\text { Time to } \mathrm{pH} 4.6 \\
(\mathrm{~h}: \mathrm{min})\end{array}$ \\
\hline \multirow{3}{*}{ R-707 } & Camel & $-0.0080^{\mathrm{b}}$ & $8: 10^{\mathrm{a}}$ \\
& Camel+0.5\% casein & $-0.0097^{\mathrm{a}}$ & $6: 46^{\mathrm{b}}$ \\
& Bovine & $-0.0099^{\mathrm{a}}$ & $5: 55^{\mathrm{b}}$ \\
& Bovine+0.5\% casein & $-0.0094^{\mathrm{a}}$ & $6: 34^{\mathrm{b}}$ \\
& 50:50 blend & $-0.0092^{\mathrm{a}}$ & $5: 48^{\mathrm{b}}$ \\
\hline \multirow{2}{*}{ Yoflex mild 1.0 } & Camel & $-0.0071^{\mathrm{c}}$ & $9: 08^{\mathrm{a}}$ \\
& Camel+0.5\% casein & $-0.0207^{\mathrm{a}}$ & $3: 20^{\mathrm{b}}$ \\
& bovine & $-0.0157^{\mathrm{b}}$ & $3: 45^{\mathrm{b}}$ \\
& Bovine+0.5\% casein & $-0.0230^{\mathrm{a}}$ & $3: 32^{\mathrm{b}}$ \\
& $50: 50$ blend & $-0.0134^{\mathrm{b}}$ & $3: 55^{\mathrm{b}}$ \\
\hline
\end{tabular}

Results are mean values of four analysis, means with the same letter across columns within culture are not significantly different $(\mathrm{p}>0.05)$, coefficient of variation $(\mathrm{CV})=5.8$ and 7.1 for $\mathrm{V}_{\max }$ of $\mathrm{R}-707$ and Yoflex mild 1.0 respectively, $\mathrm{CV}=5.6$ and 5.4 for $\mathrm{pH} 4.6$ for $\mathrm{R}-707$ and Yoflex mild 1.0 respectively. 


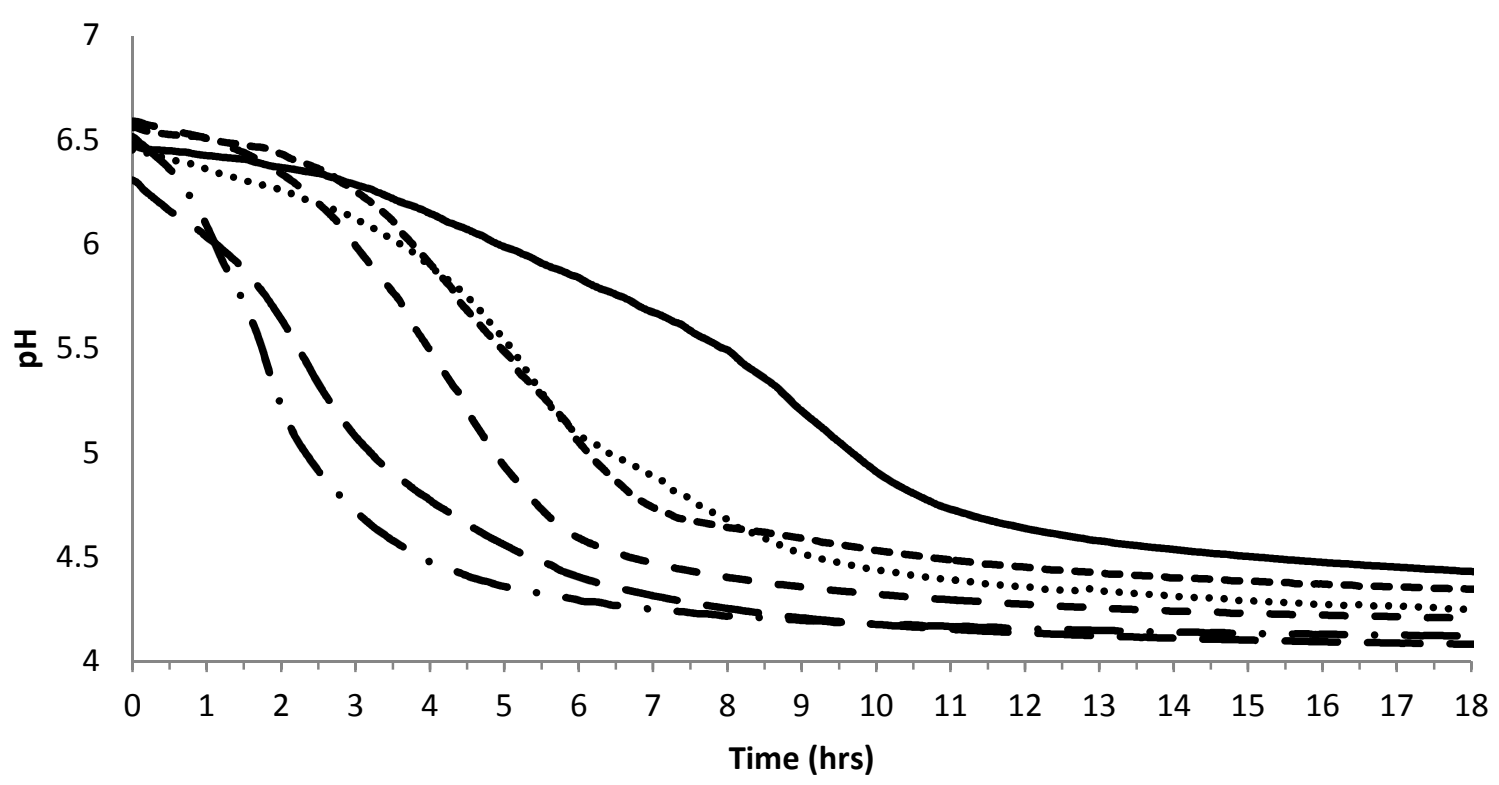

..... R-707 camel $30^{\circ} \mathrm{C}-$ R-707 bovine $30^{\circ} \mathrm{C}-\mathrm{CHN}-22$ camel $30^{\circ} \mathrm{C}$
- $\mathrm{CHN}-22 \operatorname{cow} 30^{\circ} \mathrm{C}-$ STI-12 camel $42^{\circ} \mathrm{C}-$ STI-12 bovine $42^{\circ} \mathrm{C}$ 
1

2
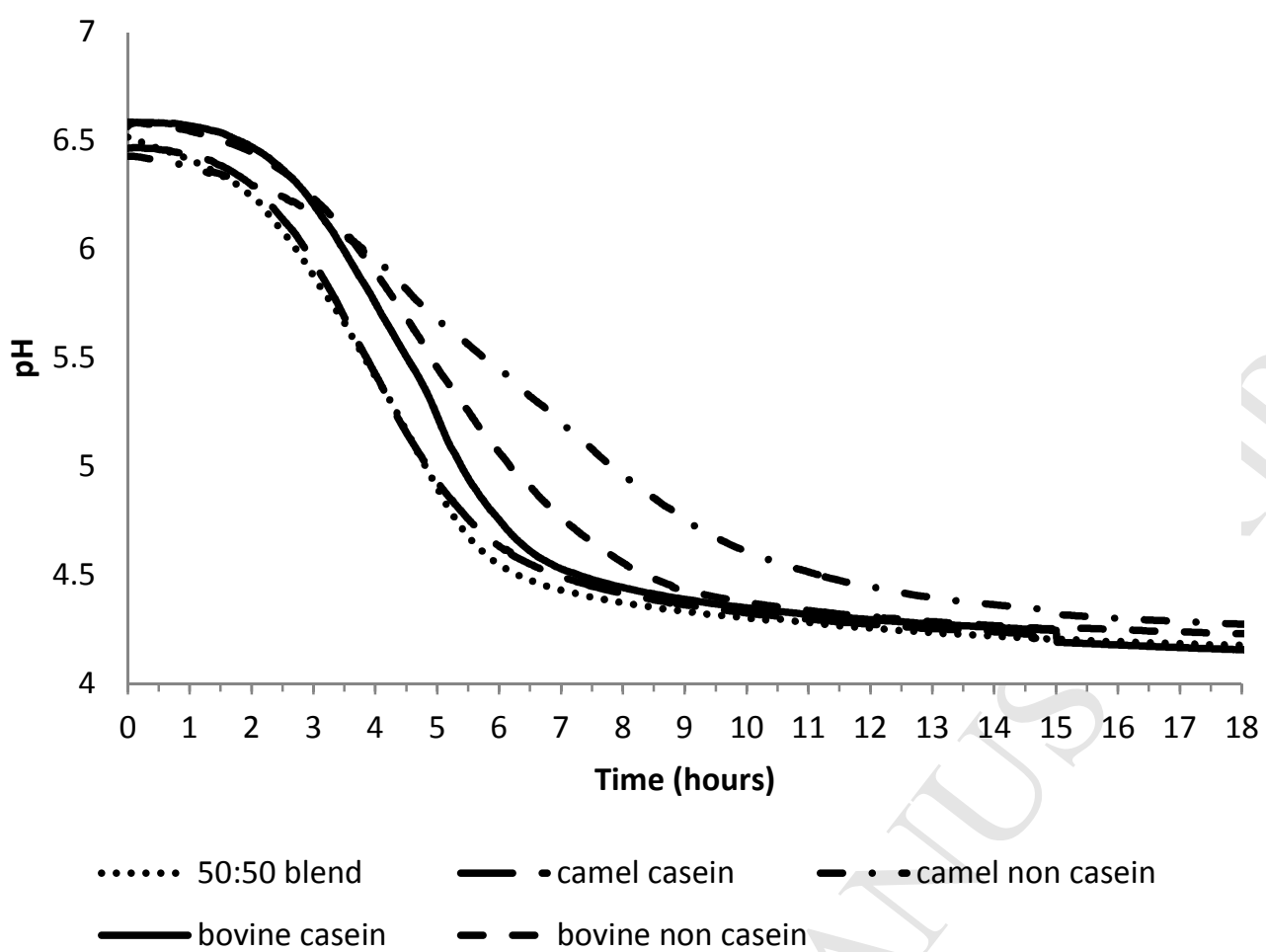


\section{Highlights}

$\checkmark$ Camel milk shows fermentation difficulties

$\checkmark$ Acidification speed of 8 commercial cultures were relatively lower in camel milk

$\checkmark$ Casein supplementation or blending improved the slow speed in camel milk

$\checkmark$ The delayed speed is due to insufficient proteolysis than the inhibitory substances 